\title{
The Preference Function of Stakeholders and Marketing Strategies for Banks in Tunisia
}

\author{
Chiraz. Rouissi ${ }^{1} \&$ Mbarek Rahmoun $^{2}$ \\ ${ }^{1}$ Assistant Professor at the University of Jeddah Elkamel Saudi Arabia, Saudi Arabia \\ ${ }^{2}$ King Abdulaziz University, Jeddah Saudi Arabia, University of Carthage, Tunisia \\ Correspondence: Chiraz. Rouissi, Assistant Professor at the University of Jeddah Elkamel Saudi Arabia, Saudi \\ Arabia. E-mail: charrouissi@yahoo.fr
}

\author{
Received: March 23, 2019 Accepted: April 25, 2019 Online Published: May 21, 2019 \\ doi:10.5539/ijms.v11n2p131 URL: https://doi.org/10.5539/ijms.v11n2p131
}

\begin{abstract}
During recent years, due to the necessary fluctuations that have impacted the financial capitalism, value creation has emerged and found a good basis especially for the company's shareholders as well as customers, suppliers, bankers, unions and of course the government. So, the birth of the notion of stakeholders is a strict notion, this theory applies to the entire economy.

Moreover, the strategic choices are an important part of the banks; hence the importance of the choice of strategy becomes paramount to deal with developments in a rapidly changing environment. An effective bank marketing strategy keeps customers educated. This paper shows recommendations as to the measures to be adopted in order to improve the marketing effectiveness of the banks.

The aim of this article is to show the importance of the preference function in banking strategic choices in Tunisia.
\end{abstract}

Keywords: preference function, strategic banking, stakeholders, shareholders

\section{Introduction}

The company consists of a set or group of people that make up the human resources of the latter in order to create value that has always been at the heart of the capitalist system. In recent years, thanks to the massive changes that have impacted the financial capitalism, value creation has emerged and found a good foundation especially for the company's shareholders as well as customers, suppliers, bankers, unions and of course the government. Hence the birth of the concept of stakeholders is a strict notion; this theory applies to the entire economy.

Moreover, the strategic choices are an important part of the banks; hence the importance of the choice of strategy becomes paramount to deal with developments in a rapidly changing environment.

At the end of the 90s, stakeholder theory appeared in particular in the managerial literature. This theory presides over the debates with the role played by the company in our society. Thus, it brings about significant progress that coincides with the emergence of other concepts that can be applied in discussions and debates about business.

In emerging countries (Aguilera \& Jackson, 2010), recent studies have recognized a rise in the factors that influence respect for corporate governance. The institutional theory (Davis, 2005), incorporates a broad understanding related to cultural dimensions as well as the formal factors of the firm.

Seal (2006), proposes an institutional theory of the agency, which determines the analysis of the management of human behaviors, largely owned societies or action management that is influenced by institutionalized practices that affect practices and practices business performance. The combination of these theories establishes the behavior of managers who has been influenced and legitimized by corporate governance according to agency theory. Institutional theory is defined as a set of formal and informal rules that affect business activity (North, 2005). In this regard, these two formal rules (government initiatives, laws, Campbell, 2007) as well as, informal institutions (corporate culture and strategy, Boliari \& Topyan, 2007) are considered antecedents to action by defining the practices of corporate governance. 
This article contains 4 hypothesis that they will be confirmed or rejected.

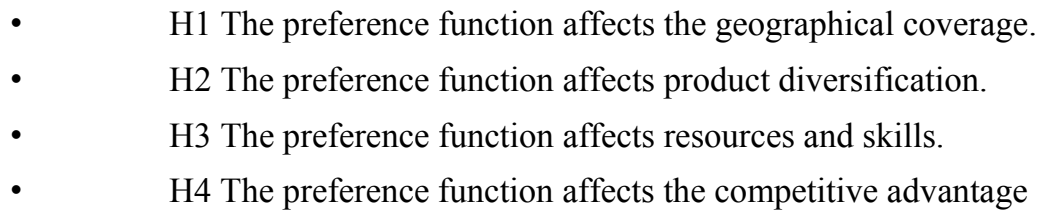

The purpose of this paper is to show the importance of the preference function in banking strategic choices in Tunisia. So, this work seeks to determine the importance of function of the preferences of stakeholders in the strategic choice of Tunisian banks.

Specifically, this article intends to provide an answer to the following question: The function preferably of stakeholders determines the strategic choice of banks?

In this sense, to address the problem posed, our article will be structured in two parts as follows:

The first part is devoted to study the theoretical foundations of the stakeholders and specifically the concepts and theories and bank strategies. And the second part will be devoted to the empirical validation and results.

\section{The preference functions of stakeholders}

This article revisits and further develops by sweeping the story of different definitions that have focused attention through the "stakeholders" research program. In fact, the term stakeholders constitute a primordial concept. This term draws attention through his conceptual scope and his theoretical debate with researchers and theorists around it.

We will expose the theoretical space that seems to be the most adequate to explain the phenomenon that captivates us. Thus, in the first part of this section, we will study the origins, the definitions and the typologies of the stakeholders.

\subsection{The Origin of the Rerm of Stakeholders}

This concept has not been stopped in the same way by all authors. Indeed, with the Stanford Research Institute (1963), which defined the concept of stakeholders as a set of essential actors to the survival and sustainability of the company. In the following table we will define the term of the stakeholders according to each author.

Table 1. Summary of Definitions of stakeholders (Gond J-P, Mercier S., 2004, pp. 383-384)

\begin{tabular}{|c|c|}
\hline Authors & Proposed definitions \\
\hline Stanford Research Institute (1963) & «group without the support of which the organization would cease to exist» (quoted in Freeman, 1984, p. 31) \\
\hline Rhenman \& Stymne (1965) & $\begin{array}{l}\text { «group that depends on the company to achieve its own goals which it depends for its existence» (quoted in } \\
\text { Carroll \& Näsi, 1997, p. 50) }\end{array}$ \\
\hline \multirow[t]{2}{*}{ Sturdivant (1979, p. 54) } & $\begin{array}{l}\text { 1) "individuals who are affected by the policies and practices of the company and and claiming a stake in its } \\
\text { business" }\end{array}$ \\
\hline & $\begin{array}{l}\text { 2) "any group whose collective behavior may directly affect the future of the organization, but not under the } \\
\text { direct control of it." }\end{array}$ \\
\hline Mitroff (1983, p. 4) & $\begin{array}{l}\text { Interest groups, stake, actors, suitors and institutions (both internal and external) that influence the business. } \\
\text { stake that affect or are affected by the actions, behaviors and policies of the company }\end{array}$ \\
\hline Freeman \& Reed (1983) & $\begin{array}{l}\text { - "Groups that have an interest in the company's actions" (p. 89) - restricted meaning (see SRI): "group or } \\
\text { individual whose business depends for survival" (p. 91) -wider (p. 91): see Freeman, 1984, p. } 46\end{array}$ \\
\hline Freeman (1984, p. 46) & $\begin{array}{l}\text { «individual or group of individuals that can affect or be affected by the achievement of organizational } \\
\text { objectives» }\end{array}$ \\
\hline Savage et al. (1991, p. 61) & «have an interest in the actions of the organization and ... have the ability to influence them» \\
\hline Jones \& Hill (1992) & «members have a legitimate right to the firm» \\
\hline Freeman \& Evan (1993) & «a group of individuals who have a right to the company» \\
\hline Clarkson (1995) & «people claiming a share of property, rights or interests in the firm» \\
\hline Mitchell \& Agle \& Wood (1997) & "Possess at least one of these three bases: power, legitimacy and state of emergency" \\
\hline Desbrières \& Charreaux (1998) & "Employees whose preference is affected by the decisions of the company" \\
\hline Kochan \& Rubinstein (2000) & "Bring resources, put some value and too much power to affect the performance and efficiency of the firm" \\
\hline Post \& Preston (2002) & $\begin{array}{l}\text { "specific elements that participate, whether voluntarily or not, in the company's ability to create value and its } \\
\text { activities and who are the main beneficiaries» }\end{array}$ \\
\hline Freeman (2004) & « those groups who are vital to the survival and success of the organization». \\
\hline Caroll et Buchholtz (2011) (Note 1) & $\begin{array}{l}\text { «External stakeholders: government (regulations, public policies), consumers, environmental stakeholders, } \\
\text { community stakeholders. }\end{array}$ \\
\hline & - Internal stakeholders: employees and any group of employees». \\
\hline
\end{tabular}


Freeman has identified the word stakeholders, articulating itself with the traditional expression "shareholders" who take only one thought on the economic side. And since, Freeman (1984) presenting a famous definition especially taken up by Carroll and Buchholtz (2000, p. 68): "A stakeholder is an individual or group of individuals who can affect or be affected by the achievement of organizational objectives". Through this perspective, the stakeholders expose the suppliers, customers, employees, investors, the community that can contribute to the performance and the growth of the firm.

Originally, a 'stakeholders' was a person to whom we entrusted a sum of money or property pending determination of its rightful owner, or a third person who entrusted their money punters waiting to know the winner.

Sometimes courts may fulfill this role while waiting to settle a property dispute or designating, where property is bequeathed to a child, an administrator pending its majority. This is an old legal concept. In France, the main stakeholders are called the notary or bailiff.

Berle and Means (1932, p. 5) present "control of big business should lead to a neutral technocracy balancing the interests of different groups in the community". These authors affirm the existence of four types of stakeholder: the clients, the employees, the community, and the shareholder.

In this perspective, Branard (1938), shows the image that "the company is envisaged as an open place where different types of relations between stakeholders intersect". However, the literature on stakeholder theory has become unsaturated in the management literature through Freeman's famous book: Strategic Management: A Stakeholder Approach (1984). As a result, stakeholder theory has developed prominently with the study of the relationship between the economy and the society and in the analysis of the social performance of firms.

Indeed, the company can be presented as specific and shared common interests. In this context, the preference function manages interest groups, and with it the company continues to exist, namely the stakeholders.

The special interest group of stakeholders can be achieved at the expense of another group which is a problem because the stakeholders have certain common interests or shared as well as other special interests that can be a source of conflict.

Indeed, sustainability and business sustainability are a shared interest of all the company's stakeholders (The Louarn \& Wils, 2001).

So, the preference function may be as follows:

\subsection{Preference Function}

Private $\alpha$. interest $+\beta$. Shared Interest ${ }^{\varepsilon} \alpha+\beta$ and constitute the relative importance of each type of interest.

Also, $\mathrm{PF}=\alpha$. Common Elements $(\mathrm{CE})+\beta$. differential elements $(\mathrm{DE})+\varepsilon$

$\mathrm{FP}=\alpha . \mathrm{CE}+\beta . \mathrm{DE}+{ }^{\varepsilon}(\alpha+\beta)$ is the relative importance of each type of interest.

In other $\alpha$ seeks the particular interest of each stakeholder while $\beta$ seeks viability

The dominant values reflect the preferences of the manager, namely, the personal equation, reputation, esteem and consideration for employees.

The scale of values in society is the set of values governing devoted a definite society, such as merit, loyalty, trust, credibility and solidarity.

The scale of values of stakeholders is the set of values forging collaborative relationships, complementarity and integration such as reciprocity and shared vision.

The mode of operation is the way in which the business is run, that is to say the management style adopted by the manager, resource allocation and organizational cutting mode.

Resources concern all material resources (physical and measurable) and intangible (knowledge, personal skills and knowledge evolve) that will allow to operate the business. They can be financial, technical, human (competence, experience and potential).

The performance of the company depends on two types of resources: tangible (logistics) and intangible (organizing intelligence).

Organizational cutting mode, concern the system used to be able to divide the company in responsibility centers (profit center, cost, investment ...).

The control procedure should promote the steering to create value: economic (material and measurable), social 
value (relational network creation with the environment) and institutional value (the pride of belonging to a reliable institution).

Value $\mathrm{MAX}=\alpha$. Economic value $+\beta .+{ }^{\delta}$ social value. Institutional value $+\varepsilon$

Table 2. Function of preference of each stakeholders (David I. Cleland ed., 1998. Field guide to project management. John Wiley and Sons.)

\begin{tabular}{ll}
\hline Stakeholders & La fonction de préférence \\
\hline Shareholder & $\mathrm{PFS}=$ As SI $+\beta$ SIS \\
Leader & $\mathrm{PFL}=$ Al SI $+\beta 1$ SIL \\
Personal & $\mathrm{PSP}=$ Ap SI $+\beta$ SIP \\
Customer & $\mathrm{PFC}=$ Ac SI $+\beta$ SIC \\
Society & $\mathrm{PFS}=$ As SI $+\beta$ SIS \\
\hline
\end{tabular}

Note. SI: self interest, PF: Preference Function, SI: Shared Interest.

\section{Marketing Banking Strategy}

For years, banks have clear strategies for securing their goals and missions for internal and external reasons, and those for the achievement and realization of profit. Managerial theory is characterized by the overvaluation of the effect of the environment on organizations. The intense environment is presented by the theory as "standardizing" factor strategies.

In fact, the word "environment" is vague and ambiguous, but can be defined as "the set of elements that are outside of the company but who have contact with her."

The environment guides the behavior of organizations; they have their support, support, brief references legitimacy with the environment (Andrew et al., 2005).

Indeed, organizations can adapt to their environment effects are the ones getting the best results (Strong et al., 2000; Venkatraman \& Prescott, 1990).

\subsection{Definition of the Strategy}

The strategy is a word constructed from two Greek words: Stratos (army) and Agos (driving). The strategy is the art of leading an army.

Several definitions have been emerged to describe the term strategy.

The dictionary Microsoft Encarta Premium 2004 gives us the following explanation:

The Strategy is a:

1) Art organize and coordinate a set of operations to achieve a goal.

2) Military: Art of the coordination of all the forces of a country to prepare for war (an offensive strategy based on mobility) or arrange a defense.

According to the Larousse dictionary defines strategy as "the art of coordinating the activities of military forces of a country". Art of coordinating actions and maneuver to achieve a goal.

The application of the strategy has become paramount in all areas. For decades, it spreads in all sectors of activity. The relationship between management and strategy is very strong. The term strategy describes several terms such as decisions, actions, processes, and resources. The word strategy is used to show all kinds of decisions, actions, processes or resources. When everything is well organized, everything will be strategic. In fact, in recent years, several writers have exposed different definitions of strategy. In what follows, we will expose a set of definitions that describe the concept of strategy. According to Chandler's strategy is the possession of the long-term goals and objectives of an organization, the acceptance of the means of action and the allocation of essential resources to achieve these goals. through this definition we can see that the proper use of resources makes it possible to avoid waste and this constitutes the second pillar of the war (economy of means). According to Octave Gelinier (1964), strategy is a goal to win the war. It applies to the company for the purpose that it tries to fight against its competitors for its sustainability. Hence, strategy is an art for successful war and in the context of the organization is the art of growing and achieving a sustainable competitive advantage. According to Igor Ansoff (2007, p. 10): "The strategy focuses on the business, not internal, but external, of the firm, and more specifically on the choice of the products it will make and the markets in which it will sell". According to Porter (1979), the strategy must build legitimate, long-term competitive advantages. 
We can observe that: 1) The strategy is presented as an art that constitutes the potential of each artist; here the strategist is fundamental that the technique deployed. 2) The strategy is an ideal combination of methods considering the environment that can bring the company to the achievement of their goal. In general, we can see that to succeed and become a strategist, it is necessary to organize and foresee a well-determined approach that presupposes the knowledge of the situation (the enemy), the prospection of the advantages capable of increasing the results and the choice of short and long-term goals. This suggests the admission of a large number of methods and methods of analysis specific to this approach as well as a desire for action.

\subsection{The Banking Strategies}

\subsubsection{The Environment and the Structure of Tunisian Banks}

After the 1980s, the banking system experienced a growing and modernized evolution, so the banking law was revised to promote competition among banks and ensure the necessary stability for the banking system.

Moreover, we can interpret that the banking system is rich because there are 30 Tunisian banks structured around the central bank of Tunisia. These banks are subdivided into 17 deposit banks, six development banks, eight offshore banks and two investment banks.

The Tunisian banking system comes under three distinct types of banks: The Central Bank of Tunisia, Tunisian banks, offshore banks.

Table 3. The banking strategies

\begin{tabular}{|c|c|c|c|}
\hline strategy & Principles & advantages & Contributions \\
\hline $\begin{array}{l}\text { Acquistion } \\
\text { strategy }\end{array}$ & $\begin{array}{l}\text {-Offensive strategy } \\
\text { - power expressed in duration }\end{array}$ & $\begin{array}{l}\text {-professionalism } \\
\text { - efficiency } \\
\text { - cordiality }\end{array}$ & -Innovation \\
\hline $\begin{array}{l}\text { reorientation } \\
\text { strategy }\end{array}$ & $\begin{array}{l}\text { - The aim is to restore flexibility and } \\
\text { range of possibilities. }\end{array}$ & $\begin{array}{l}\text { - The divestments are viewed as strategic action } \\
\text { when the environment is too risky on competitive } \\
\text { intensity, nations and financial products. }\end{array}$ & $\begin{array}{l}\text {-The bank is a source } \\
\text { of significant benefit } \\
\text { through its traditional } \\
\text { activities. }\end{array}$ \\
\hline $\begin{array}{l}\text { Consolidation } \\
\text { strategy }\end{array}$ & $\begin{array}{l}\text { - establish a change that will be } \\
\text { required for success }\end{array}$ & $\begin{array}{l}\text { - This strategy is a development phase and } \\
\text { accumulation to create value. }\end{array}$ & $\begin{array}{l}\text {-Halt the decline } \\
\text { - Try to preserve the } \\
\text { independence of the } \\
\text { institution }\end{array}$ \\
\hline The diversification & $\begin{array}{l}\text { - Seeks to add new jobs to the current } \\
\text { activities of the bank }\end{array}$ & $\begin{array}{l}\text { - widening the scope of the bank's activity and } \\
\text { imposes the use of a new set of knowledge to the } \\
\text { new competitive space in which it enters. } \\
\text { - Reduce the risks to the economic situation by } \\
\text { compensation between products with different } \\
\text { cycles (to reduce risk must diversify financial } \\
\text { assets wallet }\end{array}$ & $\begin{array}{l}\text { - seeking referrals for } \\
\text { new business sectors. }\end{array}$ \\
\hline $\begin{array}{l}\text { Specialization or } \\
\text { concentration or } \\
\text { focusing strategy }\end{array}$ & $\begin{array}{l}\text { It is to focus the activity on a market } \\
\text { segment that corresponds to a type of } \\
\text { product, client, a technology or a } \\
\text { given geographical area. }\end{array}$ & $\begin{array}{l}\text { - To develop the knowledge and make use of } \\
\text { competition. } \\
\text { - Create a unique advantage to creditworthy } \\
\text { customers. }\end{array}$ & $\begin{array}{l}\text { - Security Research } \\
\text { - The search for a } \\
\text { satisfactory size in a } \\
\text { perspective of growth. }\end{array}$ \\
\hline $\begin{array}{l}\text { Segmentation } \\
\text { strategy }\end{array}$ & $\begin{array}{l}\text { Is to cut a market under separate } \\
\text { customer together. }\end{array}$ & profitability & $\begin{array}{l}\text { - Appropriate use of } \\
\text { resources }\end{array}$ \\
\hline $\begin{array}{l}\text { Competitive } \\
\text { advantage }\end{array}$ & $\begin{array}{l}\text { According to Zolinger } 1999, \\
\text { attention must be paid to the supply } \\
\text { system in place to achieve the level } \\
\text { of quality/cost/time expected by a } \\
\text { more demanding and more } \\
\text { experienced customers. The } \\
\text { evaluations of this system change and } \\
\text { evolve. }\end{array}$ & $\begin{array}{l}\text {-Beyond the description of the procedures and } \\
\text { techniques to offer a product or service, this } \\
\text { assessment should focus on identifying the skills } \\
\text { that a bank uses to try to meet customer } \\
\text { expectations. }\end{array}$ & $\begin{array}{l}\text {-This internal analysis } \\
\text { of the banking system } \\
\text { is essential to reflect } \\
\text { on trade strategies to } \\
\text { differentiate and gain } \\
\text { a competitive } \\
\text { advantage. }\end{array}$ \\
\hline
\end{tabular}




\section{Empirical Validation}

\subsection{The Model and Research Hypotheses}

This second part underpins empirically our research proposals and we will offer them a mature approach whose heart is checking our research hypotheses. The field study will help with the collection of information actually made from a specific population - check, update and complete the data presented in the literature review.

\subsection{Justification of Epistemological Choice}

Our work is based on the positivist paradigm based on the observation of reality. The approach allows us to build a conceptual model that explains how the importance of the preference function of SH affects the banking strategic choice. This paradigm is capable of providing a stable epistemological basis for all of our work. Our problem is focused on the facts. Positivism tries to reduce phenomena to their simple elements. We will then formulate hypotheses testing. Our study is quantitative. According to this paradigm, there is only one reality. It is independent of any notice that is waiting to be explored.

\subsection{Data Collection}

Data collection is characterized by the development of a survey which is the hardware support for data collection in this survey. Indeed, this method of data collection is the most developed in the quantitative research, it can query the individuals directly by defining in advance by a qualitative approach, response categories across questions called "closed" and choosing between the proposals already made by the investigator. In fact, this method facilitates the use and coding for the statistical analysis of the responses. In our survey, we will try to group questions by theme as consistently as possible and according to the information that was established to collect and assumptions that was proposed to test. However, concerning the administration of the questionnaire, which is the next step after developing the questionnaire, it is important to note that there are several types of questionnaire administration which include mail, face to face, by phone or by computer, namely by e-mail, or none of these methods is ideal, and therefore should seek the advantages and disadvantages of each and according to the situations that arise. In our work, we have chosen the administration of the questionnaire for most banks by the method of direct maintenance as this method is most suitable for fairly long questionnaires and requires the collection of a large amount of information. In addition, this will have pretty good answers because we can clarify and restate some not understood by the respondent questions. However, this does not preclude the fact that some questionnaires will be administered by computer.

\subsection{The Sample Selection}

We will proceed to the determination of the parent population that consists of Tunisian bank branches (38 seats and bank branches) which have the characteristics for the study.

Respondents are executives and agency leaders from banks and Tunisian bank branches (ABC, ALBARAKA, AMEN BANK, ATB, BCT BFPME, BFT, BH, BIAT, BNA, BT, BTE, BTK, BTL, BTS, CITI BANK, NORTH AFRICA INTERNATIONAL BANK, STB, STUSID, TIB, Tijari Bank TQB, UBCI, and ZITOUNA UIB).

\subsubsection{Method of Data Analysis}

The counting of questionnaire data obtained will be realized through the SPSS Version 18. This software allows describing the data and performing all desired analyzes: flat sorting and multivariate methods (factor analysis, ANOVA, Multiple regression ...)

\subsubsection{Factor Analysis}

The factor analysis may be applied to each built research. This is a technique to reduce the number of factors and move to a more realistic number.

Generally, it applies to a rotation factor analysis (varimax and oblimin). This is to facilitate the interpretation of the factorial structure of the building, providing a set of useful indicators to determine whether an item is to keep or reject.

\section{Results}

This part will be devoted to the validation and the analysis of the results. Indeed, the outcome of these results will highlight the interest of SH in the strategic choice of banking. To do this, we will begin the analysis of the multiple linear regression for the 4 hypotheses. 


\subsection{Multiple Regression}

We used multiple linear regression because this analysis is one of the solutions that exist to observe the links between a quantitative dependent variable and an independent quantitative variable. To strengthen the results of our research, we used multiple regression analysis to validate or reject the remaining hypotheses. Concerning the various research hypotheses, we will apply the following approach in order to deduce if each independent variable (explanatory: X) has a significant effect or not on the dependent variable (to explain: $\mathrm{Y}$ ).

Let the hypothesis be:

$\mathrm{H} 0$ : the variable $\mathrm{X}$ has no significant effect on the variable $\mathrm{Y}$.

$H 1$ : the variable $X$ has a significant effect on the variable $Y ; p=5 \%$.

We cannot reject the null hypothesis with a very low risk of error unless:

$\checkmark \quad$ The Student " $t$ " calculated for the independent variable (X) is superior in absolute value to 1.96 (the theoretical " $t$ ").

$\checkmark \quad$ Unilateral significance is less than $5 \%(\mathrm{p}=0.05)$.

Our first step is the interpretation of the results obtained following the multiple regression between the explanatory variable "the function of preference" on the variable to explain "Banking strategy". The following table summarizes the results concerning the assumptions relating to the orientation of the preference function of the stakeholders on strategic banking choices. On our article, we have 4 hypothesis that we will confirmed or rejected.

-H1 (The preference function affects the geographical coverage).

$-\mathrm{H} 2$ (The preference function affects product diversification).

-H3 (The preference function affects resources and skills).

$-\mathrm{H} 4$ (The preference function affects the competitive advantage)

Table 4. Result of the multiple regression: effect of the variable the preference function on the strategic banking

\begin{tabular}{lllll}
\hline & Geographic Coverage & Product Diversification & Resources and skills & Competitive advantage 1 \\
\hline Constant & $4.033 \mathrm{E}-18(1)$ & $-1.182 \mathrm{E}-16(1)$ & $4.074 \mathrm{E}-16(1)$ & $-1.026 \mathrm{E}-16(1)$ \\
Power & $0.639(0)$ & $0.527(0.001)$ & $0.358(0.052)$ & $0.333(0.095)$ \\
legitimacy & $0.32(0.014)$ & $0.296(0.04)$ & $0.325(0.059)$ & $0.39(0.04)$ \\
urgency 1 & $-0.053(0.596)$ & $0.106(0.355)$ & $0.121(0.379)$ & $-0.036(0.81)$ \\
urgency 2 & $0.02(0.821)$ & $0.169(0.097)$ & $0.285(0.023)$ & $0.208(0.12)$ \\
R $^{2}$ & 0.753 & 0.686 & 0.545 & 0.456 \\
EU (F.S) & 0.00 & 0 & 0 & 0 \\
DL & 31 & 31 & 31 & 31 \\
\hline
\end{tabular}

Note. $\left({ }^{* *}\right)$ The model is significant at $\mathrm{p}<0.01$ (bilateral), $\left({ }^{*}\right)$ The model is significant at $\mathrm{p}<0.05$ (bilateral).

The Fisher test measures the overall significance of the model.

R2: coefficient of determination: measures the explanatory power of the model plus R2 close to 1 plus the explanatory power of the model is high. However, the interpretation of the results provided by the regression should not stop at the level of each variable; the researcher is also required to interpret the meaning and strength of the link between the explanatory variables and the variables to be analyzed. explain (Evrard et al., 2009). Thus, we will interpret the results of the regression at the global level.

\section{Discussion}

\section{The relationship between power and geographical coverage:}

With regard to the overall level of the regression performed on the link between the preference function and the geographical coverage, the coefficient of determination of the model $\mathrm{R}^{2}$ is equal to 0.753 . Thus, we can say that $75.3 \%$ of the variation, geographical coverage can be affected by the preference function. The predictive quality of the model is therefore good. Regarding the model's significance, the ANOVA indicates that the model is statistically significant at the 5\% threshold since Fisher's statistical value $\mathrm{F}=24.386$ is greater than the tabulated value (1.96) with a significance level of the order of $0.000(<0.05)$. So, this model is globally significant.

The results of the explanatory analysis showed that the variables power $(b=0.639, p=0)$ and legitimacy $(b=0.32$, $p=0.014$ ) have a positive and significant effect on geographic coverage. On the other hand, the state of emergency 
has an insignificant effect. That said, the preference function has a partial positive effect on geographic coverage. In doing so, hypothesis $\mathrm{H} 1$ is confirmed (the preference function affects the geographical coverage).

The model shows that power affects significantly and positively the geographical coverage. We can conclude that strategic choices include geographic coverage to determine future strategy, product diversification, resources and skills; and the positioning of competitive advantage. Moreover, by reference to the theory of the agency, Caby and Hirigoyen (2000) show that the progression of firms is refined on the basis that, as an object of human behavior, stakeholders are calculators and Opportunistic, they seek to optimize their profit, knowing that in our investigation we opted for the stakeholders that are staff, manager, shareholder, supplier and customer; Which constitute the stakeholders of the bank. Moreover, to establish a good convergence between the stakeholders of the bank, it is first necessary to build the charter of values of the bank together. Each partner working within the bank has its own personal values that come from experience, education, culture, training and strategies. Thus, each stakeholder tends to project his own choices, his own decisions based on a set of management principles, rules of conduct that fall within a hierarchy of personal values. Subsequently the problem that arises regarding this hierarchy of personal values remains in the unconscious of the individual and can be expressed as divergent to the other interests of the other stakeholders. As a result, each stakeholder will use his/her hierarchy of personal values and risks opposing the hierarchy of personal values of other stakeholders; Which is likely to lead to divergence and, in turn, the beginning of conflicts of interest (principle of the agency theory).

These results are presented through a scale of 1 to 5 passing from Never, Rarely, Sometimes, Frequently to Always. The power of the stakeholders is of paramount importance, while that of the manager still has $56 \%$ of his capacity to influence banking strategies. Moreover, the shareholder's power is frequent because it has $46 \%$ of its capacity to influence banking strategies. On the other hand, the power of the client has $13 \%$ of its capacity to influence strategies. Regarding the power of the supplier, it is rare since it uses only $10.8 \%$ of its capacity to influence strategies. Finally, staff power still accounts for $54 \%$ of the ability to influence banking strategies. Power emerges through the decision of stakeholders who have different objectives, forming an agreement to accomplish their goals through the strongest preferences between them (Dean \& Sharfamn, 1993).

\section{The power of the Leadership}

This study shows that there is an ability to influence the stakeholders that belong to the board of directors such as shareholders, managers or bank staff and their representatives. Consequently, these can affect the sustainability and performance of banks. In spite of the influence of the stakeholders on the performance of the bank, the literature indicates that there are only a few stakeholders who have influence mechanisms, notably those who are members of the board and who may be involved in Strategic decision-making (Hartaska \& Nadolnyak, 2007). The main role of the executive is to oversee proper management within the bank; and its power still accounts for $56 \%$ of its capacity to influence banking strategies. Similarly, we appreciated the sense of intuition among bank branch managers because of divergent interests with other stakeholders. In this sense, stakeholder participation in strategic decision-making has been one of the most important processes of governance and strategy (Christensen \& Westenholz, 1999). In addition, the participation of the Council refers here to the overall level of participation.

\section{The power of the client}

Clients make up the national population of low, middle and high income. In addition, customers always need more consideration, especially with regard to the process of obtaining loan that varies by category. For example, how banks organize their methods for granting individual and collective loans is formally different (Sharma \& Zeller, 1997; Aghion \& Morduch, 2000; Ghatak, 1999). Therefore, it is crucial for banks to set up client representatives so that when strategic decisions are made, they correspond to the needs and objectives of clients.

At this level, we have shown that banks are interested not only in customer orientations and opinions but also in their opinions on the product, an approach that has been espoused in the past (Pischke, 1995). From the observations, the customer can guide the strategic choices of the banks at the rate of $13 \%$ of its capacity. This is due to the competition and knowledge of customers and their experiences in trying various products and services. The bank has a marketing approach since customers' needs go first, Participation on boards of directors is very important. Thus, the main role of banks is to provide the most relevant information for customers in terms of the necessary products, means of delivery, financial support and ways to attract and retain them. This information is very useful for banks because it allows them to design the products and services that best meet the needs of customers; which is one of the most important ways for banks to involve clients in order to achieve performance. 


\section{The Power of Staff}

To ensure the continuity of operation and sustainability of every entity in the world, the bank needs to hire staff to succeed in its sustainability and achieve its performance. In our study, staff power still accounts for $54 \%$ of the ability to influence banking strategies, as middle managers and other employees, such as loan officers, are heavily involved in bank decision-making. They are often in direct contact with clients so that they can bring a lot of relevant and transparent information on suggestions and advice on how to improve and innovate delivery services and processes; which is likely to generate highly competitive strategies (Lapenu \& Pierret, 2005). In addition, employees have direct access to detailed information about the bank's operations (Clap ham \& Cooper, 2005). In some cases, they can be involved in the bank's strategic decision-making process by giving them the opportunity to participate in the long-term growth of the bank. Consequently, the staff develops the feeling of integration and belonging to the bank, the main motive of its motivation.

\section{The power of the supplier}

Supplier power is not as important as it has only $10.8 \%$ of its capacity to influence strategies. In fact, this stakeholder brings national and international expertise that can only be of benefit to banks. Similarly, the supplier helps banks through its assistance, among others, training and internships. In the same vein, Hartaska (2005) found that the integration of suppliers into the board is not effective. Again, it is important to have a balance for the participation of all stakeholders in decision-making.

\section{The power of the shareholder}

Bank shareholders and/or investors hold important roles in the decision-making process. Indeed, the power of the shareholder is frequent because it has $46 \%$ of its capacity to influence banking strategies. These shareholders appear in different forms. Some are international organizations or NGOs, others are members of national societies that contribute to increased bank capital; and some are members in national and international institutions that hold shares.

As with any organization, the board of directors of banks is mainly represented by shareholders who hold more shares. Shareholders are divided into two classical and mixed types (Labie, 2001) according to the interests of each. Classical shareholders are motivated, and their participation in boards or decision-making processes is based primarily on for-profit decision making. On the other hand, mixed shareholders or social shareholders would like to have a certain level of profit while having a social impact. For them, the board of directors should understand a variety of stakeholders and the decisions taken should meet the bank's objectives, so that the most important role of shareholders is to oversee the management and good governance of the bank and Making decisions that lead to the sustainability and continuity of operations in the bank.

From the results we can classify stakeholders into two types, internal stakeholders and external stakeholders (Rousseau \& Shperling, 2003). Internal stakeholders are the stakeholders who belong to the bank and who are the shareholders (members of the board of directors) (Barako, Hancock, \& Izan, 2006; Hussainey \& Al-Najjar, 2011) Managers (managers in headquarters and branch heads in branches). These stakeholders are directly affected, positively or negatively, by the actions of the bank. They constitute the groups whose continued participation is necessary for the survival of the bank. External stakeholders are those who are outside the bank but can influence the survival of the bank (Harrison, 1996).

\section{Geographical coverage}

The banking sector has in recent years developed an important network of branches but has not yet initiated any concentration movements. In addition, the Tunisian banking system has managed to set up a large network of representations and agencies, since there are currently more than 1,450 branches, approximately one agency per 7,400 inhabitants. In doing so, the geographical presence is a force for the banking sector in Tunisia. Similarly, stakeholders who are close to banking institutions and who share the same interests and values, ensure the exclusive distribution of the associated products and services thanks to a complete geographical banking coverage. In order to do this, we asked ourselves, among other things, the following question: To what extent do stakeholders' preferences influence decisions about geographical coverage?

Shareholder preferences account for $40.5 \%$ of its ability to influence decisions about geographic coverage. The shareholder has the power to decide and to establish or cancel a branch or a bank branch in the national or regional territory. As for the manager's preferences, they present Still $75.7 \%$ of its capacity to influence decisions on geographical coverage. Client preferences frequently account for $43.2 \%$ of its ability to influence decisions about geographic coverage. Indeed, proximity is the main criterion of the choice of the bank for the customers. As regards suppliers' preferences, they still account for $13.5 \%$ of its capacity to influence decisions on geographical 
coverage. In addition, staff preferences still account for $64.9 \%$ of its ability to influence decisions about geographic coverage.

\section{The relationship between power and product diversification}

It is commonly accepted that power is asking to a negotiating process that provides for two kinds of power; the internal power through which the development of the strategy is political and is based on negotiation; and the external power through which the firm exerts influence over others such as their partners and stakeholders to negotiate strategies in their interests. The zone manager must manage the entire portfolio of products in his zone. If this portfolio is very broad, the des-economies of scale are likely to be considerable. This type allows a better adaptation to geographical specificities (diversity of clienteles, politically unstable countries).

For the overall level of the regression performed on the link between the "Product Diversification" and the "preference function", the coefficient of determination of the $\mathrm{R}^{2}$ model is equal to 0.686 . Thus, we can say that $68.6 \%$ of the variation in product diversification can be predicted by the preference function. Subsequently, the model's prediction quality is good.

Regarding the model's significance, the ANOVA indicates that the model is statistically significant at the 5\% threshold since Fisher's statistical value $\mathrm{F}=17.482$ is greater than the tabulated value (1.96) with a significance level of the order of $0.000(<0.05)$. Following this result, the model is globally significant. The results of the explanatory analysis revealed that the variables power $(b=0.527, p=0.001)$ and legitimacy $(b=0.296, p=0.04)$ have a positive and significant effect (at 5\%). on product diversification. All the same, state of emergency 2 has a significant effect at $10 \%(b=0.169, p=0.097)$ on product diversification, while state of emergency 1 does not have a significant effect. So, the preference function has a partial positive effect on product diversification. Thus, hypothesis $\mathrm{H} 2$ is confirmed (So the preference function affects product diversification).

However, the assessment of the nature of the power of the stakeholders is decisive in the different stages of development of the bank, since the decision-making methods differ according to the stage of development of the banks, but some options may influence the bank according to the duration.

\section{The relationship between power and resources and skills}

As for the overall level of the regression performed on the link between the "resources and skills" and "the preference function", the coefficient of determination of the model $\mathrm{R}^{2}$ is equal to 0.545 . In other words, $54.5 \%$ of the resource and skill variation can be predicted by the preference function. The predictive quality of the model is also average. Regarding the model's significance, the ANOVA indicates that the model is statistically significant at the $5 \%$ threshold since Fisher's statistical value $\mathrm{F}=9.574$ is greater than the tabulated value (1.96) with a significance level of the order of $0.000(<0.05)$. In doing so, the model is globally significant.

The results of the explanatory analysis indicated that the variables power $(b=0.358, p=0.052)$ and legitimacy $(b$ $=0.325, \mathrm{p}=0.059$ ) have a significant positive effect at $10 \%$ on resources and skills. On the other hand, state of emergency 2 has a significant effect at $5 \%(b=0.285, p=0.023)$ on resources and skills, whereas state of emergency 1 does not have a significant effect. Therefore, the preference function has a partial positive effect on resources and skills, so that hypothesis $\mathrm{H} 3$ is confirmed (So the preference function affects resources and skills).

In the same vein, we note from these interpretations that the resources and skills of the bank enable it to build its strategic capacity. In addition, power exerts influence on the bank through resources and skills. A way of determining the strategic capacity of a bank is to assess its strengths and weaknesses (which gives it an advantage or a disadvantage). We identify these strengths and weaknesses by analyzing the resources available in each of the strategic areas of activity: production capacity, personnel, power influences on resources and skills.

\section{The relationship between power and competitive advantage}

With regard to the overall level of the regression performed on the link between the preference function and the competitive advantage, the coefficient of determination of the model $\mathrm{R}^{2}$ is equal to 0.456 . Thus, we can say that $45.6 \%$ of the variation in the competitive advantage can be affected by the preference function. The predictive quality of the model is therefore average. Regarding the model's significance, the ANOVA indicates that the model is statistically significant 5\% threshold since Fisher's statistical value $\mathrm{F}=6.706$ is greater than the tabulated value (1.96) with a significance level of the order of $0.000(<0.05)$. So, this model is globally significant. The results of the explanatory analysis have shown that the variables state of emergency $2(b=0.208, p=0.12)$ and legitimacy $(b=0.39, p=0.04)$ have an effect $10 \%$ significant positive on competitive advantage. On the other hand, the power $(b=0.333, p=0.095)$ has a significant effect at $10 \%(b=0.285, p=0.023)$ on the competitive advantage, whereas the state of emergency 1 does not have an effect. significant. That said, the preference function has a partial positive effect on competitive advantage. Thus, the hypothesis $\mathrm{H} 4$ is confirmed (So the preference 
function affects the competitive advantage). All in all, the "HS preference function has an impact on the strategic banking choice" is partially confirmed.

Thus, the hypothesis H 4 is verified (The power affects the competitive advantage). Moreover, the power comes from the ability of competitors to influence the bank's profitability through price, quality, time and quantity. In addition, geographical coverage is becoming a tool for the modernization of the state and the civil service. It facilitates a more rational allocation of resources both to public authorities and to banks, it also allows them considerable time savings, so that it generates positive spin-off far beyond its direct economic effects. The banks form an open system where there is constant interaction within the environment. In the light of a constantly evolving global economy, all organizations are seeking competitive advantages as changes present opportunities as well as challenges. Similarly, Johnson et al. (2003) note that organizations need to find means of exploitation by developing new skills, that old acquired skills are rapidly eroded due to changes in both internal and external environments.

As a result, we have

\section{- $\quad H 1$ is confirmed (The preference function affects the geographical coverage). \\ - $\quad \mathbf{2} 2$ is confirmed (The preference function affects product diversification). \\ - $\quad \mathrm{H3}$ is confirmed (The preference function affects resources and skills). \\ - $\quad \mathrm{H} 4$ is confirmed (The preference function affects the competitive advantage)}

\section{Conclusion}

After formulating our research hypotheses, the methodological tools needed to test our research model in the Tunisian context. At this level, we recall that we adopted a positivist epistemological posture accompanied by a hypothetical-deductive methodological positioning. We wanted to test the assumptions taken in the literature from a sample of 37 Tunisian banking offices and branches. In the fourth chapter, we first checked the dimensionality of the scales of measure adopted at the end of an analysis of the principal component (APC). After that, we tested the reliability of these scales through the Cronbach alpha coefficient. Before proceeding with the multiple regressions, we examined whether the prerequisites for the application of this methodology have been met. At the same time, we examined the presence of aberrant observations. No extreme observations were detected. The results of the multiple regressions and the analyzes of the variance carried out show that 4 hypotheses put forward are confirmed. We can deduce from these results that the preference function is influenced by marketing strategic banking choices; and then we can verify our research proposal.

The study makes a unique contribution by developing and examining methods or applying a method in the banking sector with our dependent variable (preference function) that has not already been used. However, when dealing with this issue, we were exposed to methodological difficulties such as the interpretation of the results, the distinction between the effect of each calculated measure and the data collection procedure. This empirical model applied in Tunisia constitutes in itself a contribution. In fact, most assumptions have been confirmed; Power both affects geographic coverage, product diversification, resources and skills and competitive advantage. As a result, legitimacy both affects geographic coverage, product diversification, competitive advantage and resources and skills. Moreover, the state of emergency does not affect geographical coverage. The state of emergency affects product diversification, resources and skills. Ultimately, the model is highly significant; which confirms the global hypothesis and asserts that the preference function affects the marketing and commercial strategies choice of banking.

In our view, one of the most important aspects of the conclusions of this article is that they highlight the relevance of the previous research that we have exploited. All the same, if our results open up a slightly wider path of research, much remains to be done to improve our understanding of the issues. Some points of interest in future research are worthy of mention, especially when it comes to finding that the relationship between the preference function and the banking strategic choices is reciprocal. Moreover, throughout our research, we have shown that the preference function significantly affects the bank's strategic choices. Not with standing, the particular interest of the preference function also depends on strategic banking choices; which can constitute a new field of study.

\section{References}

Andrew, O., \& Sofian, S. (2012). Individual Factors and Work Outcomes o Employee Engagement. Procedia Social and Behavioral Sciences, 40, 498-508. https://doi.org/10.1016/j.sbspro.2012.03.222

Mcbarnet, D. (2009). Corporate Social Responsibility Beyond Law, Through Law, for Law. SSRN Electronic Journal. https://doi.org/10.2139/ssrn.1369305 
Aapaoja, A., \& Haapasalo, H. (2014, January 16). A Framework for Stakeholder Identification and Classification in Construction Projects. Retrieved from https://www.scirp.org/journal/PaperInformation.aspx?paperID=42090

Barako, D., Hancock, P., \& Izan, H. (2006). Factors Influencing Voluntary Corporate Disclosure by Kenyan Companies. Corporate Governance: An International Review, 14(2), 107-125. https://doi.org/10.1111/j.1467-8683.2006.00491.x

Cleland, D. I. (2007). Strategic Management: The Project Linkages. The Wiley Guide to Managing Projects, 206-222. https://doi.org/10.1002/9780470172391.ch9

Dean, J., \& Sharfman, M. (1993). Procedural Rationality in the Strategic Decision-Making Process. Journal of Management Studies, 30(4), 587-610. https://doi.org/10.1111/j.1467-6486.1993.tb00317.x

Gottschalk, P. (n.d.). Theories of the Firm. E-Business Strategy, Sourcing and Governance. https://doi.org/10.4018/9781599040042.ch001

Gardès, N. (2018). Développement et validation d'une échelle de mesure de la compétence relationnelle du dirigeant et analyse de son impact sur l'accompagnement financier. Finance Contrôle Stratégie, 21(1). https://doi.org/10.4000/fcs.2038

Harrison, S., \& Stjohn, C. (1996). Managing and Partnering with External Stakeholders. Academy of Management Executive, 10(2), 46-60. https://doi.org/10.5465/ame.1996.9606161554

Hassan, R., \& Hassan, R. (n.d.). Corporate Governance Effect on Ownership and Control in Firms: An Empirical Evidence from Pakistan. Retrieved from https://www.academia.edu/29779706/Corporate_Governance_Effect_on_Ownership_and_Control_in_Firm s_An_Empirical_Evidence_from_Pakistan

Hartarska, V. (2005). Governance and Performance of Microfinance Institutions in Central and Eastern Europe and the Newly Independent States. World Development, 33(10), 1627-1643. https://doi.org/10.1016/j.worlddev.2005.06.001

Hond, F., Bakker, F., \& Neergaard, P. (2016). Managing Corporate Social Responsibility in Action. London: Routledge. https://doi.org/10.4324/9781315593494

Hussainey, K., \& Al - Najjar, B. (2011). Future - Oriented Narrative Reporting: Determinants and Use. Journal of Applied Accounting Research, 12(2), 123-138.https://doi.org/10.1108/09675421111160691

Labie, M. (2001). Corporate Governance in Microfinance Organizations: Along and Winding Road. Management Decision, 39(4), 296-302.https://doi.org/10.1108/00251740110391466

Le Louarn, J.-Y., \& Wils, T. (2001). L'évaluation De La Gestion Des Ressources Humaines: Du Contrôle Des Coûts Au Retour Sur L'investissement Humain. Paris: Éditions Liaisons.

Nassreddine, G., \& Anis, J. (2012). Corporate Governance: Behavioral Approach and Cognitive Mapping Technique. SSRN Electronic Journal. https://doi.org/10.2139/ssrn.2144670

Mcbarnet, D. (2009). Corporate Social Responsibility Beyond Law, Through Law, for Law. SSRN Electronic Journal. https://doi.org/10.2139/ssrn.1369305

Parker, S. (2009). The Economics of Entrepreneurship. United Kingdom, Cambridge. https://doi.org/10.1017/CBO9780511817441

Pischke, J. (1995). Individual Income, Incomplete Information, and Aggregate Consumption. Econometrica, 63(4), 805.https://doi.org/10.2307/2171801

Parker, C. T., Wigley, S., \& Garrity, G. M. (2003). Exemplar Abstract for Schaalia georgiae. The NamesforLife Abstracts. https://doi.org/10.1601/ex.5782

Quidt, J., Fetzer, T., \& Ghatak, M. (2016). Group Lending Without Joint Liability. Journal of Development Economics, 121, 217-236. https://doi.org/10.1016/j.jdeveco.2014.11.006

Rousseau, D. M., \& Shperling, Z. (2003). Pieces of the Action: Ownership and the Changing Employment Relationship. The Academy of Management Review, 28(4), 553. https://doi.org/10.2307/30040747

Urgeghe, L. (2009). Commercialisation Et Financement De La Microfinance: Quels Enjeux De Gouvernance? Reflets Et Perspectives De La Vie Economique, Xlviii(3), 39. https://doi.org/10.3917/rpve.483.0039

Venkatraman, N., \& Prescott, J. (1990). Environment-Strategy Coalignment: An Empirical Test of Its 
Performance Implications. Strategic Management Journal, 11(1), 1-23. https://doi.org/10.1002/smj.4250110102

Zardkoohi, A., \& Paetzold, R. (2004). Ownership and The Changing Employment Relationship: A Comment on Rousseau and Shperling. The Academy of Management Review, 29(4), 556. https://doi.org/10.2307/20159069

\section{Note 1}

Carroll, A. B., \& Buchholtz, A. K. (2011). Business and Society: Ethics and sustainability, and stakeholder management (8th Ed.). South western cengage learing.

\section{Copyrights}

Copyright for this article is retained by the author, with first publication rights granted to the journal.

This is an open-access article distributed under the terms and conditions of the Creative Commons Attribution license (http://creativecommons.org/licenses/by/4.0/). 